\title{
Court says US law applies to Antarctic waste cleanup
}

Washington. A US federal court ruling that an environmental law applies to Antarctica could seriously affect the way in which the US National Science Foundation (NSF) handles waste on the continent.

Environmental activists say the decision tells NSF "to look before you leap" by forcing it to follow a 23-year-old law that until now has applied only to activities on
NEPA does not apply to activities outside the United States but that NSF and other agencies must provide a similar review of any proposal that affects the environment under an executive order issued by President Jimmy Carter.

EDF says that requiring NSF to follow NEPA would lift the "shroud of secrecy" surrounding its actions in Antarctica and those of other federal agencies around the world. It argues that NSF did not adequately consider the impact on the environment of incineration when it decided in 1991 to end the open burning of waste at McMurdo and switch to incineration, and that incineration would generate heavy metals and other highly toxic pollutants. In May 1991 it brought suit against NSF, and three months later it appealed against a ruling by the district court that NEPA did not apply.

Government lawyers representing NSF told the

A cargo ship waits outside McMurdo Station in Antarctica to transport a year's worth of boxed waste material back to the United States.

US soil. But NSF officials say that they are already "responsible stewards" of the environment and that the added regulatory review could disrupt fruitful international scientific cooperation by delaying some projects until all aspects of the environmental law are met.

On 29 January, the US Court of Appeals for the District of Columbia reversed a lower-court decision that NSF was not bound by the National Environmental Policy Act (NEPA). The suit was brought by the Environmental Defense Fund (EDF), which opposes the construction of an incinerator at McMurdo Station, the largest of three US research bases in Antarctica and the centre of US operations on the continent. The government has 45 days to ask the entire court of appeals to review the decision and 60 days to petition the US Supreme Court to take on the case. If the Clinton administration decides not to appeal, the lower court would then decide whether NSF followed the procedures spelled out under NEPA before building the incinerator.

NEPA requires US federal agencies to conduct an extensive and public review of any activity that might have a significant impact on the environment; it also gives dissatisfied parties the right to sue. US government lawyers have argued that court that NEPA could conflict with the laws of foreign countries and that its lengthy reviews could drive away potential research partners and prevent NSF from taking full advantage of scientific opportunities. They also argued that NEPA could dictate policies that might conflict with national security or other considerations.

NSF officials believe that the advocacy group's real purpose is to prevent the incineration of waste in Antarctica. Inadvertently, that goal has been partly achieved as ble for NSF to burn some food wastes in the new incinerator.

"We've had a problem dealing with [the water content in] frozen material", says Peter Wilkness, director of polar programmes for NSF. "Of course, the wastemainly uneaten food - is not toxic; you can eat it. What's ironic is that we can't burn the stuff that wouldn't pollute."

During the past two years, NSF has shipped more than 50 tons of food wastes to New Zealand. But New Zealand is no longer willing to accept the waste, Wilkness says, and NSF is looking for another location. With the last ship due to leave McMurdo by the end of February before winter sets in, he says "we'll have to move fast".

Jeffrey Mervis technical problems have made it impossi-
NEWS IN BRIEF

Washington. The American Chemical Society (ACS) has agreed to a cash settlement that ends a running battle with a local school system over the tax status of a successful subsidiary. As part of a negotiated settlement with the Columbus (Ohio) school system, Chemical Abstracts Services (CAS) will pay the schools $\$ 2$ million and an annual fee, $\$ 275,000$ this year and adjusted for inflation in future years.

The school system in Columbus, where CAS is located, is funded chiefly by local property taxes; it argues that CAS does not deserve its classification as a tax-exempt charity because the service benefits ACS's 140,000 members rather than the public. A second point of contention was the several million dollars each year that CAS contributes to ACS coffers, which the school board views as profit but which ACS uses to support the society's non-revenue programmes.

In June 1992, a local court ordered CAS to pay annual taxes of $\$ 800,000$, backdated to 1980 when the suit was filed. CAS appealed against the decision and at the same time persuaded state legislators to pass a law guaranteeing its tax-exempt status, precluding the school system from collecting taxes for 1993 and beyond. That statement, combined with a desire by new CAS leadership to put the issue to rest, provided a basis for the negotiated settlement reached last month.

Jenna Roberts

Washington. Energy Secretary Hazel O'Leary is the latest addition to a growing list of officials in the Clinton administration who are less than enthusiastic about the \$8.5-billion Superconducting Super Collider (SSC), on which her department this year is spending $\$ 517$ million. Meeting the media last week for the first time, O'Leary expressed considerably less zeal for the project than her predecessors, who took their cues from their bosses, presidents George Bush and Ronald Reagan. "I am in a balancing mode between our commitment to international cooperation on a high-energy physics experiment and the problem of reducing the federal deficit", she said.

"And it's not going to be my call. But I can say that I'm not passionate about it."

Presidential science adviser John Gibbons was similarly equivocal when he appeared before Congress two weeks ago, and the new director of the Office of Management and Budget, Leon Panetta, was a sharp critic of the SSC as a member of Congress. Although the accelerator was brought up during a recent presidential retreat, President Bill Clinton has not as yet signalled whether he intends to abandon a campaign promise to support the project.

Jeffrey Mervis 